\title{
Removal of Methylene Blue from Aqueous Solution by Using Electrical Arc Furnace (EAF) Slag
}

\author{
Suhanna Natalya Mohd Suhaimy* and Luqman Chuah Abdullah \\ Department of Chemical and Environmental Engineering, Universiti Putra Malaysia, 43400 UPM Serdang, Malaysia
}

*Corresponding author:

tel: $+60-012-3202690$

email:suhanna1285@gmail.com

Received: August 3, 2018

Accepted: December 14, 2018

DOI: $10.22146 / \mathrm{ijc} .40910$

\begin{abstract}
In recent years, environmental protection has gained a major concern. In line with the rapid growth of various industries, high amount of effluent has been generated and discharged to the environment. One of the concerns is the presence of synthetic dye in the wastewater stream, as it may endanger human and aquatic life. In this experiment, the Electrical Arc Furnace (EAF) slag has been used as an adsorbent to remove methylene blue from the aqueous solution. Batch experiments have been conducted, and the effects of initial dye concentration, $p H$, adsorbent dosage and temperature were studied respectively. Chemical treatment has been performed to modify the adsorbent. The results reveal that treated EAF Slag has higher efficiency in removing methylene blue compared to raw EAF slag. More pores have been exposed, and impurities on the adsorbent's surface have been removed, to enhance better removal efficiency. The maximum adsorption capacity for treated EAF is $14.2029 \mathrm{mg} / \mathrm{g}$ and for raw EAF Slag is $9.615 \mathrm{mg} / \mathrm{g}$. The maximum removal percentage for treated EAF Slag is $71.01 \%$, whereas raw EAF shows 37.19\% removal at $\mathrm{pH}$ 10. Both raw EAF Slag and treated EAF slag fits the data for the Langmuir isotherm model which obeys the monolayer adsorption process.
\end{abstract}

Keywords: adsorption; Electrical Arc Furnace (EAF) slag; batch experiment

\section{- INTRODUCTION}

Wastewater can be defined as any water that leaves from houses and industries through the main drain pipe which is contaminated by chemical residues through human activities. The wastewater must be treated in order to remove the dyes before releasing it to the environment [1]. The release of industrial wastewater has a significant negative impact on the ecosystems which could harm the environment and hydrosphere organisms [2].

Methylene blue or known as methylthioninium chloride is a dark green crystalline powder. It is a basic synthetic dye which commonly used to impart color for cotton, wool, and silk, for an attractive finishing [3]. The overexposure to methylene blue may cause the following effects: dizziness, nausea, and abdominal pain.

The textile manufacturing process is one of a waterintensive process which discharges a huge amount of wastewater. Approximately $200 \mathrm{~L}$ of water is required to produce $1 \mathrm{~kg}$ of textile [4]. Wastewater from the textile industries is contaminated with other chemical substances such as soap of metals, hydrogen peroxide, acids and alkali [5]. High $\mathrm{pH}$ and temperature may poses threats to the aquatic life, eventually will lead to the species distinction. Carcinogens compounds from textile wastewater can cause damage to human living tissues through metabolism disruption and eventually lead to cancer [6]. The presence of dyes will limit the light penetration in water, which will cause retardation of the photosynthesis process and eventually will disrupt the food chain of the aquatic life [7].

The application of EAF slag as an adsorbent in this experimental work has double benefits, transforming the waste product generated from the Electric Arc Furnace operation, which can be used in wastewater treatment as well as reducing the amount of EAF slag to be disposed to the municipal landfill. In steel production industries, iron ore as the primary raw material are melted at high temperature, in the equipment known as electric arc furnace. There are two possible expected products generated which are carbons steel or ferrous 
steel, which later will be used in various applications. At the same time, the undesirable product from the process is a substance called Electric Arc Furnace Slag has been generated. An adsorbent can be considered as a low cost adsorbent if its presence in abundance in nature, requires less processing or it is a waste materials, which is the byproduct from other industries [8]. Generally, it is composed of impure components such as metal oxide and lime [9]. It has been fully utilized and widely used in the field of agriculture as a fertilizer and also a field of civil as road construction material [10]. Slag has been an alternative compound, apart from granular activated carbon in wastewater treatment due to its sportive characteristics [11]. Apart from having a high melting point and its porous structure, slag can be chemically treated to modify the surface charge to adsorb the desired adsorbate on its active sites [12].

The application of slag as an adsorbent has been conducted, and it was found that $80.03 \mathrm{mg} / \mathrm{g}$ of reactive dyes have been removed by using the surface modified EAF slag [9]. Steel slag is capable to remove Manganese ions, positively charged ions, with the removal percentage of more than $95 \%$ in batch experimental adsorption process [13]. Thus, it has shown that the EAF slag is a potential adsorbent for the real application. Adsorption is an effective method for water decontamination process [14]. In addition, the adsorption method is known to be low cost operating process, as well as an easy operation method compared to other wastewater treatment methods [15].

\section{- EXPERIMENTAL SECTION}

\section{Materials Preparation}

The EAF slag was obtained from a local steel manufacturing company located in Peninsular of Malaysia. The slag was sieved using a mechanical sieve shaker, followed by washing thoroughly with distilled water to remove the debris trapped on the surface of the EAF slag particles. 600-micron slag particles were used in this study. It was then dried in the oven for $24 \mathrm{~h}$ at $90^{\circ} \mathrm{C}$.

The treated slag was prepared by adding the EAF slag into $1 \mathrm{M}$ of hydrochloric acid. The solution was allowed for mixing for $2 \mathrm{~h}$. The treated EAF slag was then washed with distilled water to remove the acid residue and dried in the oven for $24 \mathrm{~h}$ at $90^{\circ} \mathrm{C}$. Hydrochloric acid is used to activate EAF, and it is expected to improve uptake of dye by EAF through altering of physical properties which leads to increase in surface porosity and surface area of the treated EAF slag [16].

All the chemicals and reagents used in this experimental work were analytical grade, from Merck.

\section{Procedure}

The methylene blue stock solution with a concentration of $1000 \mathrm{ppm}$ was prepared by adding an accurate amount of methylene blue powder with distilled water. Few series of dilution were performed to prepare a different concentration of the dye solution which was used to develop the calibration curve.

To determine the effect of $\mathrm{pH}$, adsorbent dosage and initial concentration, batch adsorption experiment are carried out by adding raw EAF slag and treated EAF slag into the dye solution. A series of dye solution was prepared with the $\mathrm{pH}$ of the solution ranging $\mathrm{pH} 2$ to 10 , adsorbent dosage ranging from 0.1 to $0.5 \mathrm{~g}$ and a concentration ranging from 60 to $180 \mathrm{ppm}$.

Raw EAF slag $(0.5 \mathrm{~g})$ and treated EAF slag $(0.5 \mathrm{~g})$ were mixed with $100 \mathrm{ppm}$ of methylene blue dye solution in a series of conical flasks for $2 \mathrm{~h}$ at $150 \mathrm{rpm}$. The pHs of the solution was adjusted by using $0.1 \mathrm{M}$ hydrochloric solution and $0.1 \mathrm{M}$ sodium hydroxide solution. The solution was then filtered, and the concentrations were determined using the UVspectrophotometer.

\section{Characterization of adsorbent}

The surface morphology of raw EAF slag and treated EAF slag were observed using a Scanning Electron Microscope (SEM Hitachi, Japan). The elemental composition on both samples was analyzed using Energy Dispersive X-ray Spectroscopy (EDX) using the same instrument.

The specific surface area and single point pore volume were analyzed using a Surface Area Analyser (Micromeritics, USA) by applying Brunaeur Emmet and Teller (BET) test method. The surface area was determined by physical adsorption of a gas on the surface of the adsorbent and by calculating the amount 
of adsorbate gas corresponding to a monomolecular layer on the surface.

\section{Removal efficiency, adsorption capacity, and adsorption isotherm}

The removal percentage (\%) is calculated by using Eq. 1 and the amount of adsorbate adsorbed per unit mass of adsorbent is calculated using Eq. 2 [13].

$\frac{\mathrm{C}_{0}-\mathrm{C}_{\mathrm{e}}}{\mathrm{C}_{0}} \times 100$
$\frac{\mathrm{C}_{0}-\mathrm{C}_{\mathrm{t}}}{\mathrm{m}} \times \mathrm{V}$

$\mathrm{C}_{0}$ and $\mathrm{C}_{\mathrm{e}}$ are the initial and final concentration of the Methylene blue solution in $\mathrm{mg} / \mathrm{L}$. $\mathrm{C}_{\mathrm{t}}$ is the concentration of contact time. $\mathrm{V}$ is the volume of the dye solution in $\mathrm{L}$ whereby $\mathrm{m}$ is the mass (dosage) of adsorbent used in the experimental work.

Equilibrium data were analyzed using the Freundlich isotherm model and Langmuir isotherm model for both samples. The Freundlich isotherm model is given in Eq. 3, whereby $\mathrm{k}$ and $\mathrm{n}$ are the Freundlich constant which can be obtained from the graph plot [13].

$\log \mathrm{q}_{\mathrm{e}}=\log \mathrm{k}_{\mathrm{f}}+\frac{1}{\mathrm{n}} \log \mathrm{C}_{\mathrm{e}}$

The Langmuir isotherm model is given in Eq. 4, whereby $\mathrm{b}$ and $\mathrm{q}_{\mathrm{m}}$ are the Langmuir constant which can be obtained from the graph plot [13].

$\frac{c_{e}}{q_{e}}=\frac{1}{b q_{m}}+\frac{c_{e}}{q_{m}}$

\section{- RESULTS AND DISCUSSION}

\section{Characterization of Raw EAF Slag and Treated EAF Slag}

The surface morphology of both raw EAF slag and treated EAF slag were examined using a Scanning Electron Microscope (SEM). The results reveal that the pores on the surface are more significant after the treatment process as shown in Fig. 1(b), as the flocs - like impurities as shown in Fig. 1(a) has been removed and exposing the coarser surface. The presence of pores on the surface of the EAF slag confirmed its porosity. The removal of those impurities has exposed more pores on the adsorbent's surface, which eventually increased the efficient removal of the adsorbate.

The samples were further analyzed using the Energy Dispersive X-ray (EDX) spectroscopy. The results revealed that the elemental composition in weight percentage (wt.\%) has a significant difference in the elements, before and after the chemical treatment. The results for the chemical characterization are shown in Table 1.

From the data tabulated in Table 1, the existing elements in the EAF slag were $\mathrm{C}, \mathrm{Mg}, \mathrm{Al}, \mathrm{Si}, \mathrm{S}, \mathrm{Ca}, \mathrm{Mn}$ and Fe. Treatment with acid has removed $13.4 \%$ of silicon and $29.38 \%$ of calcium, as shown in Table 1 .

Table 1. Elements present in raw EAF slag and treated EAF slag

\begin{tabular}{lcc}
\hline \multirow{2}{*}{ Element } & \multicolumn{2}{c}{ Composition (wt.\%) } \\
\cline { 2 - 3 } & Raw EAF slag & Treated EAF slag \\
\hline $\mathrm{C}$ & 11.63 & 31.65 \\
$\mathrm{Mg}$ & 3.19 & 2.61 \\
$\mathrm{Al}$ & 9.28 & 6.77 \\
$\mathrm{Si}$ & 19.03 & 5.99 \\
$\mathrm{~S}$ & 0.66 & 0.00 \\
$\mathrm{Ca}$ & 35.49 & 6.11 \\
$\mathrm{Mn}$ & 3.58 & 3.49 \\
$\mathrm{Fe}$ & 17.14 & 43.39 \\
\hline
\end{tabular}

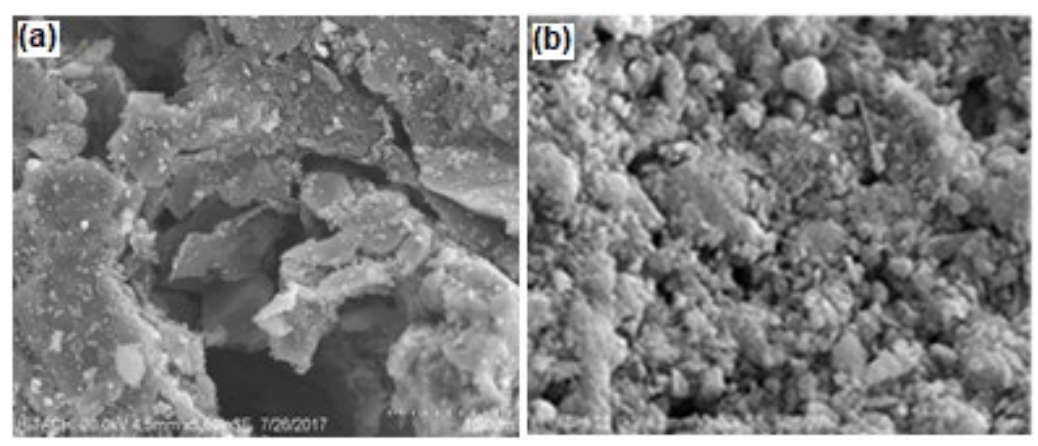

Fig 1. Surface morphology of (a) raw EAF slag and (b) treated EAF slag 
Hence, the flocs-like impurities as observed in Fig. 1(a), were mainly composed of silicon and calcium as the major component. After treatment, the composition of carbon and iron were dominant. The composition of carbon has increased by $20.02 \%$ whereby the composition of iron has increased by $26.25 \%$. EAF slag typically contains more than $25 \%$ of iron oxide [17]. More pores will be available for adsorption to occur when the impurities have been removed after the treatment process.

As the pores were observed from the Scanning Electron Microscope (SEM), further analysis to evaluate the particle size, specific surface area, and pore diameter has been conducted. The Brunaeur Emmet and Teller (BET) test has been performed, and the results are shown in Table 2.

The data shown in Table 2 reveals that the surface area and pore volume of treated EAF slag was higher compared to raw EAF slag. Particle size, pore diameter, and specific surface area are the main factors affecting the adsorption capacity of the adsorbent [16].

\section{Adsorption Study}

\section{Effect of $\mathrm{pH}$}

The $\mathrm{pH}$ of dye solution is one of the significant factors affecting the uptake of methylene blue by both raw EAF slag and treated EAF slag. $\mathrm{pH}$ is an important factor for dye adsorption, which it directly affects the dissociative and adsorptive ability of the dye onto the surface of the adsorbent [20]. Based on Fig. 2, both raw EAF slag and

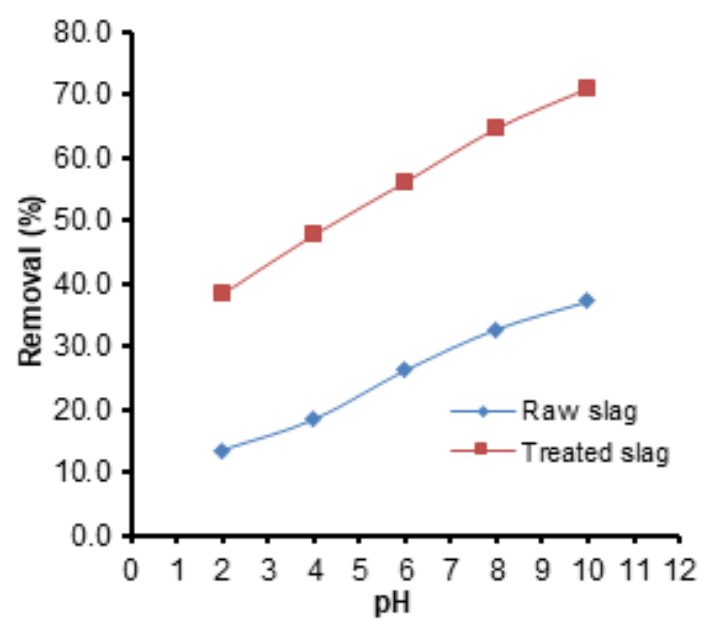

Fig 2. Removal percentage of methylene blue dye against $\mathrm{pH}$ of dye solution treated EAF slag showed the maximum removal at $\mathrm{pH}$ 10 , which are $37.19 \%$ and $71.01 \%$, respectively. At $\mathrm{pH} 10$, the adsorption capacity demonstrates by the raw EAF slag is $7.44 \mathrm{mg} / \mathrm{g}$ and it has shown a significant increase for treated EAF slag which is $14.21 \mathrm{mg} / \mathrm{g}$.

In the lower $\mathrm{pH}$ solution, the presence of $\mathrm{H}^{+}$ions will compete with methylene blue, which is a cationic dye to occupy the adsorption site, which will eventually reduce the dye uptake [13]. As the $\mathrm{pH}$ of the solution increase, the removal of methylene blue increased due to the electrostatic attraction forces between the adsorbent and the dye, as it will attach to the vacant binding sites on the adsorbent.

\section{Effect of adsorbent dosage}

The removal percentage of methylene blue dye and adsorption capacity by both raw EAF slag and treated EAF slag increases when the amount of adsorbent increase due to the availability of surface area for the adsorption site [10]. In this batch adsorption study, the adsorbent dosages varied from 0.1 to $0.5 \mathrm{~g}$. As shown in Fig. 3, treated EAF slag showed higher removal percentage

Table 2. Surface area and pore volume data

\begin{tabular}{lll}
\hline Parameter & Raw EAF slag & Treated EAF slag \\
\hline $\begin{array}{l}\text { BET Surface Area } \\
\left(\mathrm{m}^{2} / \mathrm{g}\right)\end{array}$ & 1.38000 & 1.477100 \\
$\begin{array}{l}\text { Single Point Pore } \\
\text { Volume }\left(\mathrm{m}^{3} / \mathrm{g}\right)\end{array}$ & 0.05498 & 0.054860 \\
\hline
\end{tabular}

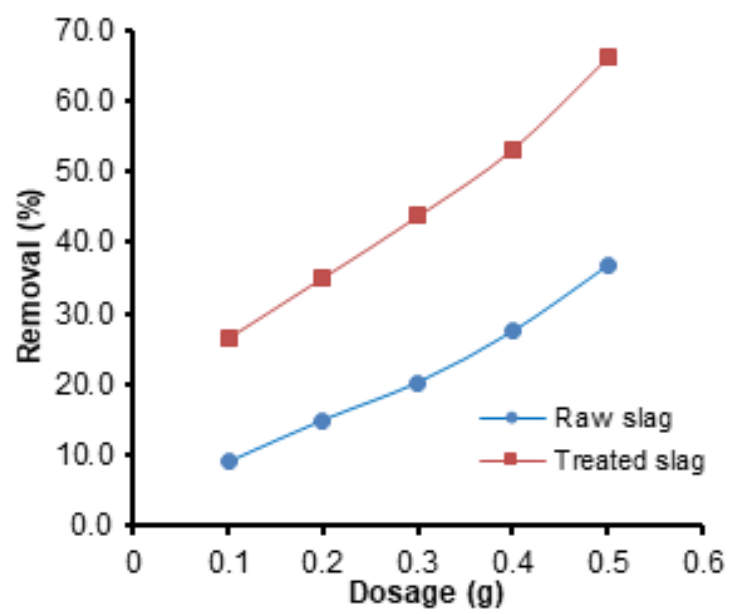

Fig 3. Removal percentage of methylene blue dye against adsorbent dosage 
compared to raw EAF slag at a fixed adsorbent dosage. The highest dye uptake is $66.01 \%$ by using the treated EAF slag which is $29.26 \%$ higher compared to the removal percentage by using the raw EAF slag. The adsorption capacity increases from 7.35 to $13.203 \mathrm{mg} / \mathrm{g}$, by using the treated EAF slag.

\section{Effect of initial concentration}

The results represented in Fig. 4 reveals that the removal percentage of both raw EAF slag and treated EAF slag is inversely proportional to the initial concentration of the dye solution. At lower concentration, the dye can be easily occupied onto the adsorption sites. Increasing the concentration will result in decreasing the dye uptake due to the limited active sites on the adsorbent's surface, lowering the adsorption process to take place [19]. At a fixed value of initial concentration, treated EAF slag demonstrates higher removal efficiency compared to raw EAF slag. Raw EAF slag demonstrates the highest removal of $49.24 \%$ at $60 \mathrm{ppm}$, with the adsorption capacity of 5.909 $\mathrm{mg} / \mathrm{g}$. Treated EAF slag demonstrate the highest removal of $80.12 \%$ at $60 \mathrm{ppm}$, with the adsorption capacity of $9.615 \mathrm{mg} / \mathrm{g}$.

\section{Adsorption isotherm}

Based on the Freundlich isotherm model as shown in Fig. 5, the linear coefficient for raw EAF slag is 0.9872

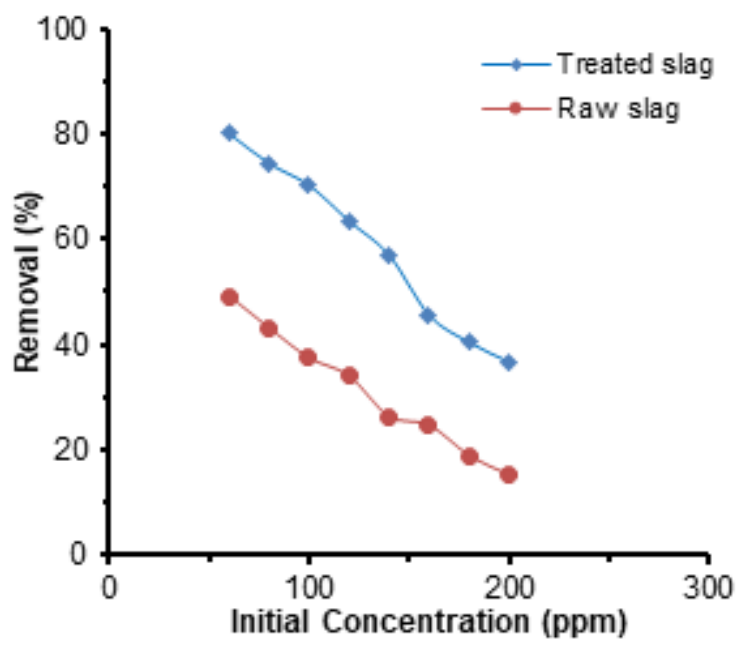

Fig 4. Removal percentage of methylene blue dye against initial concentration

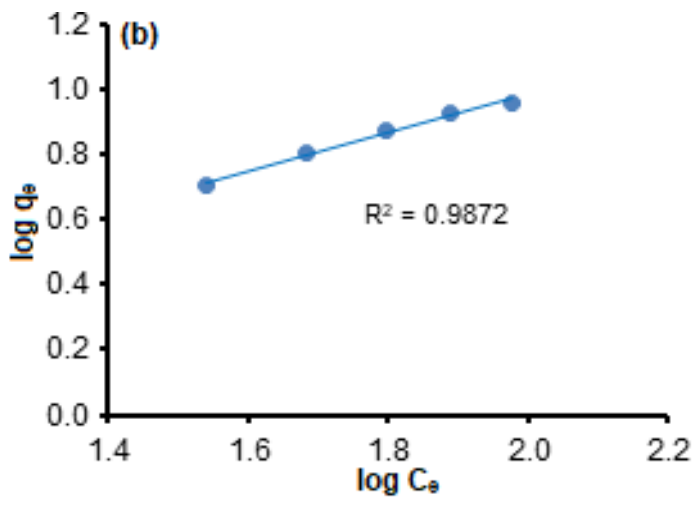

Fig 5. Freundlich isotherm model for (a) raw EAF slag and (b) treated EAF slag
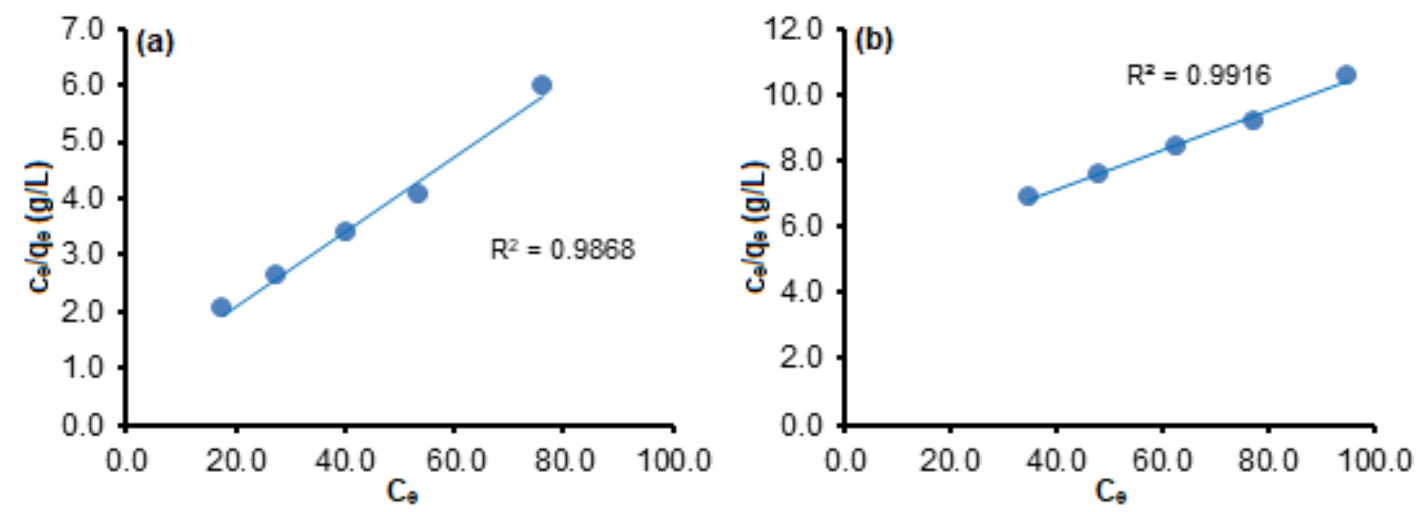

Fig 6. Langmuir isotherm model for (a) raw EAF slag and (b) treated EAF slag 
and treated EAF slag is 0.8821 . As for the Langmuir isotherm model shown in Fig. 6, the linear coefficient for raw EAF slag is 0.9916 and treated EAF slag is 0.9868 . Based on the results, it reveals that both raw EAF slag and treated EAF slag fits the data for the Langmuir isotherm model compared to the Freundlich isotherm model. It may be due to the homogeneous distribution of active sites on the surface of the EAF slag surface, as the Langmuir equation assumed that the surface is homogeneous [20].

\section{- CONCLUSION}

Treated EAF slag improved the methylene blue removal efficiency, as more surface area has increased after the treatment process, as shown in the BET test results. As the impurities have been removed through the chemical treatment process, more adsorption sites were exposed to the adsorption process to occur and increase the dye removal efficiency. The results reveal that treated EAF slag has higher removal efficiency compared to raw EAF slag. The maximum removal percentage for treated EAF slag is $71.01 \%$, whereas raw EAF shows $37.19 \%$ removal at $\mathrm{pH} 10$. Both raw EAF slag and treated EAF slag fits the data for the Langmuir isotherm model which obeys the monolayer adsorption process.

\section{- REFERENCES}

[1] Chiou, M.S., and Li, H.Y., 2003, Adsorption behavior of reactive dye in aqueous solution on chemical cross-linked chitosan beads, Chemosphere, 50 (8), 1095-1105.

[2] Walsh, G.E., Bahner, L.H., and Horning, W.B., 1980, Toxicity of textile mill effluents to freshwater and estuarine algae, crustaceans and fishes, J. Environ. Pollut. A, 21 (3), 169-179.

[3] Khanday, W.A., Marrakchi, F., Asif, M., and Hameed, B.H., 2017, Mesoporous zeolite-activated carbon composite from oil palm ash as an effective adsorbent for methylene blue, J. Taiwan Inst. Chem. Eng., 70, 32-41.

[4] Ghaly, A.E., Ananthashankar, R., Alhattab, M., and Ramakrishnan, V.V., 2014, Production, characterization and treatment of textile effluents: A critical review, J. Chem. Eng. Process Technol., 5 (1), 1000182.

[5] Holkar, C.R., Jadhav, A.J., Pinjari, D.V., Mahamuni, N.M., and Pandit, A.B., 2016, A critical review on textile wastewater treatments: Possible approaches, J. Environ. Manage., 182, 351-366.

[6] Akarslan, F., and Demiralay, H., 2015, Effects of textile materials harmful to human health, Acta Phys. Pol. A, 128 (2B), B407.

[7] Garg, V.K., Amita, M., Kumar, R., and Gupta, R., 2004, Basic dye (methylene blue) removal from simulated wastewater by adsorption using Indian rosewood sawdust: A timber industrial waste, Dyes Pigm., 63 (3), 243-250.

[8] Bailey, S.E., Olin, T.J., Bricka, R.M., and Adrian, D.D., 1999, A review of potentially low-cost sorbents for heavy metals, Water Res., 33 (11), 2469-2479.

[9] Xue, Y., Hou, H., and Zhu, S., 2009, Adsorption removal of reactive dyes from aqueous solution by modified basic oxygen furnace slag: isotherm and kinetic study, Chem. Eng. Sci., 147 (2-3), 272-279.

[10] Majid, Z.A., Hong, F.W., Rosmi, M.S., Ismail, N., Suriani, A.B., Dalila, A.R., and Rusop, M., 2014, Removal of reactive dyes from aqueous solution by modified electric arc furnace slag, Adv. Mater. Res., 832, 804-809.

[11] Lim, J.W., Chew, L.H., Thomas, S.Y.C., Tezara, C., and Yazdi, M.H., 2016, Overview of steel slag application and utilization, MATEC Web Conf., 74, 00026.

[12] Duan, J., and Su, B., 2014, Removal characteristics of Cd(II) from acidic aqueous solution by modified steel-making slag, J.Chem. Eng., 246, 160-167.

[13] Zahar, M.S.M., Kusin, M.F., and Muhammad, S.N., 2015, Adsorption of manganese in aqueous solution by steel slag, Procedia Environ. Sci., 30, 145-150.

[14] Dąbrowski, A., 2001, Adsorption - from theory to practice, Adv. Colloid Interface Sci., 93 (1-3), 135224.

[15] Geetha, K., and Velmani, N., 2015, Diverse technology and methods for dye treatment: A review, Asian J. Chem., 27 (4), 1177-1184. 
[16] Gharsalli, A., Bagane, M., Porte, C., Havet, J.L., and Ammar, S., 2017, Response surface optimization and modeling of ammonium chloride activation process of bentonite, Courrier du Savoir, 22, 61-68.

[17] Liang, H., Zhou, S., Chen, Y., Zhou, F., and Yan, C., 2015, Diatomic coated with $\mathrm{Fe}_{2} \mathrm{O}_{3}$ as an efficient heterogeneous catalyst for degradation of organic pollutants, J. Taiwan Inst. Chem. Eng., 49, 105-112.

[18] Mittal, A., Kaur, D., Malviya, A., Mittal, J., and Gupta, V.K., 2009, Adsorption studies on the removal of coloring agent phenol red from wastewater using waste materials as adsorbents, $J$. Colloid Interface Sci., 337 (2), 345-354.

[19] Wang, F.Y., Wang, H., and Ma, J.W., 2010, Adsorption of cadmium(II) ions from aqueous solution by a new low-cost adsorbent-bamboo charcoal, J. Hazard. Mater., 177 (1-3), 300-306.

[20] Foo, K.Y., and Hameed, B.H., 2014, Insight into the modelling of adsorption isotherm systems, Chem. Eng. J., 156 (1), 2-10. 